\title{
PENGARUH MOLEKUL PENGARAH STRUKTUR TERHADAP MODIFIKASI ZEOLIT ALAM UNTUK PADATAN PENDUKUNG AMOBILSASI SEL KHAMIR
}

\author{
Phaffia rhodozyma
}

\author{
Ahmad Suseno \\ Laboratorium Kimia Fisik Jurusan Kimia Universitas Diponegoro
}

\begin{abstract}
ABSTRAK
Modifikasi zeolit dari bahan zeolit alam telah dilakukan dengan menggunanakan pereaksi silika dan alumina berasal dari zeolit alam, tetrabutilamonium thiosianida sebagai kation basa organik, setiltrimetilammonium bromida sebagai molekul pengarah struktur dan natrium silikat untuk memperkaya kandungan silikat.

Tahapan modifikasi dilakukan melalui destruksi basa, hidrotermal, dilanjutkan dengan proses kalsinasi pada temperatur $550^{\circ} \mathrm{C}$. Hasil modifikasi selanjutnya dikarakterisasi mengguna-kan FTIR, $X R D$, serta pengukuran pori dengan metoda adsorpsi gas.

Hasil penelitian menunjukkan bahwa padatan hasil modifikasi memiliki karakter mikrostruktur padatan berpori dengan kristalinitas tinggi dan ukuran pori rerata sebesar $27 \AA$. Uji aplikasi menunjukkan bahwa padatan hasil modifikasi dapat digunakan sebagai padatan pendukung amobilisasi sel Khamir Phaffia rhodozyma.
\end{abstract}

Kata kunci: zeolit alam, ukuran pori, molekul pengarah struktur

\section{PENDAHULUAN}

Rekayasa material berpori dengan menggunakan senyawa-senyawa organo-kation sebagai molekul pengarah struktur biasanya dilakukan dengan proses hidrotermal (Barrer,1982). Dengan demikian secara teoritik zeolit alam yang semula mempunyai ukuran pori kecil akan dapat dimodifikasi sehingga memiliki ukuran pori yang lebih besar sebagaimana ukuran pori yang dimiliki oleh zeolit sintetis (Beck, 1991; Beck, 1992; Vansant, 1997; Vansant,2000; Li et al,2000). Tetrametil-ammonium (TMA) dan Tetrabutil-ammonium (TBA) merupakan kation yang telah banyak digunakan dalam modifikasi pori zeolit. Konsep pengarahan dimaksudkan sebagai fenomena yang terjadi pada saat proses pembentukan gel atau inti dimana molekul pengarah struktur akan mengatur kerangka tetrahedral ke bentuk bentuk geometri tertentu. Setelah kristalisasi tercapai molekul pengarah struktur akan terperangkap dalam rongga, saluran atau lapisan struktur yang terbentuk
(Vansant, 1990; Zones,1994; Ishizaki, 1998,Li et.al, 1998). Dalam rangka meningkatkan daya guna zeolit alam indonesia sebagai material berpori maka dalam penelitian ini akan dilakukan modifikasi pori zeolit dari bahan zeolit alam Wonosari untuk selanjutnya digunakan sebagai padatan pendukung pada imobilisasi sel Khamir P. rhodozyma penghasil pigmen karotenoid penting dalam akuakultur.

Riset ke arah pengembangan ukuran pori material jenis zeolit dari yang berukuran kecil menjadi lebih besar pada dasarnya didorong oleh upaya untuk lebih meningkatkan pemakaian bahan anorganik berukuran pori besar oleh kalangan industri (Jacobsen, 2001;Abe et al., 1995). Hasil Penelitian Hong-Ping Lin (2001) menunjukkan bahwa proses hidrotermal dengan penambahan molekul pengarah struktur amonium kuarterner pada material silika mampu meningkatkan porositasnya.

METODE PENELITIAN 
Bahan: Bahan yang digunakan dalam penelitian ini adalah zeolit alam yang berasal dari daerah Wonosari yang lolos ayakan 200 mesh, Bahanbahan kimia dengan kualitas p.a sebagai berikut: CTMABr (cethyl-trimethylammonium bromida), $\mathrm{NaOH}, \mathrm{Na}_{2} \mathrm{SiO}_{3}, \mathrm{HF}, \mathrm{H}_{2} \mathrm{SO}_{4}, \mathrm{HCl}$, aceton, TBASCN (tetrabuthyl ammoniumthiosianat).

Cara kerja: Diawali dengan pengambilan zeolit kering kemudian digerus halus dan diayak menggunakan ayakan ukuran 200 mesh. Sampel zeolit alam selanjutnya direndam dalam larutan HF 1\%, sehingga menjadi zeolit aktif. Zeolit aktif kemudian didestruksi dengan padatan $\mathrm{NaOH}$. Hasil destruksi dilarutkan dalam aquades, kemudian disentrifuse dan dipisahkan sehingga diperoleh larutan supernatan sebagai sumber silika dan alumina. Sejumlah garam Silikat ditambah, kemudian diaduk. Selajutnya direaksikan dengan molekul pengarah struktur TBASCN 0,2M dan ditambahkan larutan surfaktan CTMABr 0,4M dengan tetap diaduk. Masing-masing larutan campuran tersebut selanjutnya diatur $\mathrm{pH}$ hingga 11 hingga terbentuk gel.

Gel yang telah terbentuk dimasukkan dalam tabung teflon dengan tertutup rapat, dilanjutkan proses hidrotermal pada temperatur $120{ }^{\circ} \mathrm{C}$. Padatan hasil hidrotermal kemudian dicuci, dan diteruskan proses kalsinasi pada suhu $550{ }^{\circ} \mathrm{C}$. Karakterisasi dilakukan dengan mengukur geomteri mikrostruktur, kristalinitas dengan cara berturut-turut: metode adsorpsi gas, difraktometer sinar-X (XRD) Shimadzu X-2000 dengan metode bubuk. Aktivitas amobilisasi dilakukan secara adsorpsi dengan mencampurkan kultur cair sel khamir Phaffia rhodozyma pada zeolit alam maupun zeolit hasil modifikasi pada kondisi suhu kamar, dengan varisi waktu perendaman (penggojokan) dengan shaker. Hasil amobilisasi disimpan dalam freezer dan diuji viabilitasnya dengan melihat pertumbuhannya dalam medium cair.

\section{HASIL DAN DISKUSI}

Pada bagian ini akan dibahas pengaruh penambahan molekul pengarah struktur TBA terhadap karakter zeolit termodifikasi. Selain itu pada penelitian ini juga ditambahkan jenis surfaktan yang lebih panjang rantai hidrokarbonnya yaitu cethyltrimethyl ammonium bromida (CTMA) dengan harapan modifikasi terhadap pori zeolit menjadi lebih signifikan keberhasilannya. Pada bagian barikutnya juga akan dibahas aplikasi zeolit alam dan zeolit termodifikasi pada proses imobilisasi sel khamir Phaffia rhodozyma. Proses karakterisasi akan dilihat pengaruh komposisi molekul pengarah struktur terhadap geometri mikropori yang terdiri atas ukuran pori, luas permukaan, volume pori dan kristalinitas zeolit termodifikasi.

\section{Analisis Mineral Zeolit Alam}

Pada analisis mineral zeolit alam ini akan dilakukan dengan tiga metode yaitu analisis difraksi sinar-X, spektofotometri inframerah dan AAS. Zeolit yang berasal dari Wonosari ini diduga mengandung tiga tipe mineral zeolit yang dominan beberapa mineral zeolit lainnya sedikit termasuk mineral non zeolit lain yang berjumlah kecil. hasil analisis disajikan pada gambar 1 . Dari difraktogram material tersebut ditemukan adanya puncak tinggi pada daerah $2 \theta=25,58^{\circ}$; $27,65^{\circ} ; 13,39^{\circ}$ yang merupakan ciri khas dari kelompok mordenit. Pada difraktogram juga muncul puncak-puncak lain yakni pada $2 \theta=22,17^{\circ}: 9,69^{\circ} ; 28,20^{\circ}$ yang menandakan adanya jenis mineral zeolit lainnya yaitu 
klinoptilolit. Difraktogram juga menunjukkan adanya ketidakmurnian (impurities) dari mineral non zeolit. Adanya puncak tinggi dan tajam pada $2 \theta=26,54^{\circ}$ menunjukkan adanya kuarsa. Berdasarkan hasil perhitungan data-data difraktogram XRD berkitan dengan komposisi mineral zeolit alam dari perbandingan luasan intensitas tertinggi masing-masing mineral menunjukkan bahwa zeolit alam terbut terdir dari: 52,15\% mordenit; 39,82\% Klinoptilolit dan $8,02 \%$ adalah kuarsa.

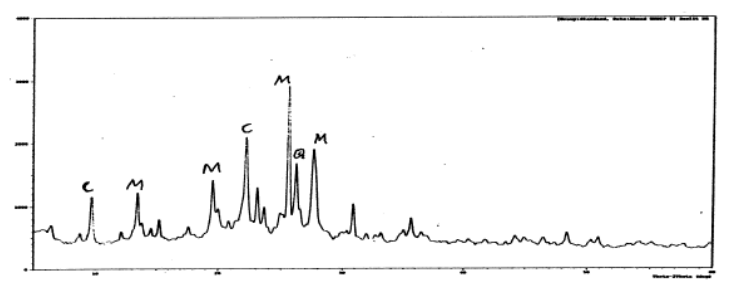

Gambar 1. Difraktogram zeolit alam wonosari M. Mordenit, $\mathrm{C}=$ klinoptilonit, $\mathrm{Q}=$ kuarsa

Karakterisasi selanjutnya dilakukan dengan spektrofotometri inframerah untuk mengetahui jenis vibrasi antar atom dalam material tanah ini. Hasil analisis ditampilkan pada gambar 2. Dari spektra inframerah, dapat dilihat adanya serapan kuat pada 1047,3 $\mathrm{cm}^{-1}$ yang menunjukkan adanya vibrasi ulur (stretching) asimetri dari internal tetrahedra baik dari Si-O, hal ini sesuai dengan apa yang kemukakan oleh Flanigen et.al (1971) dimana adanya serapan khas pada daerah $1250-950 \mathrm{~cm}^{-1}$ untuk zeolit baik alam mapun sintesis.

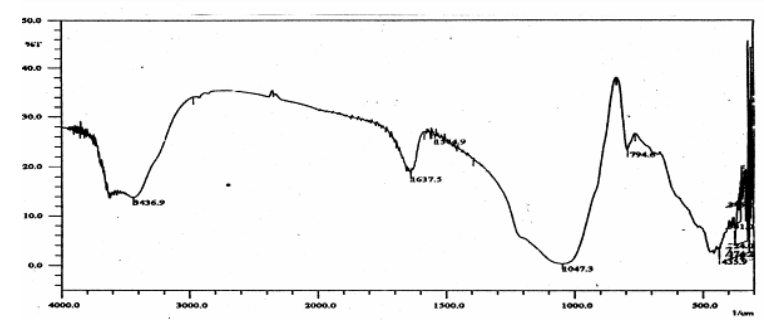

Gambar 2. Spektra inframerah zeolit alam Wonosari
Selain itu ada serapan pada $435 \mathrm{~cm}^{-1}$ yang menunjukkan vibrasi tekuk (bending) T-O, puncak tajam pada $794 \mathrm{~cm}^{-1}$ yang menunjukkan vibrasi ulur (stretching) simetri pada exsternal linkage dan puncak $1637,5 \mathrm{~cm}^{-1}$ diduga sampel telah mengadsorpsi senyawa air. Adanya vibrasi pada $1047 \mathrm{~cm}^{-1}$ dan $794 \mathrm{~cm}^{-1}$ menurut Flanigen et.al (1971) memperkuat dugaan bahwa zeolit alam Wonosari tersebut didominasi oleh jenis mordenit.Hasil karakterisasi dengan AAS menunjukkan bahwa rasio $\mathrm{Si} / \mathrm{Al}$ dari zeolit alam asal Wonosari sekitar 5, hal ini didukung pula oleh hasil-hasil penelitian sebelumnya (suseno,2003). Adapun penentuan ukuran pori, luas permukaan dan volume pori zeolit alam berturut-turut adalah 16,19 $\AA$; 34,24 m²/g; 26,36 $\mathrm{x} 10^{-3} \mathrm{~cm}^{3} / \mathrm{g}$.

\section{Analisis Mikrostruktur Zeolit Hasil Modifikasi}

Hasil karakterisasi yang disajikan pada tabel.1 terlihat adanya perubahan pada tiap parameter akibat penambahan molekul pengarah struktur TBA (ZCBA) Peningkatan rerata ukuran pori terjadi hampir $70 \%$ dari rerata ukuran pori zeolit alam. Demikian juga untuk parameter luas permukaan dan volume pori juga mengalami peningkatan.

Tabel 1. Hasil analisa terhadap luas permukaan, volume pori dan jari-jari pori

\begin{tabular}{|c|c|c|c|}
\hline $\begin{array}{c}\text { Nama } \\
\text { Sampel }\end{array}$ & $\begin{array}{c}\text { Luas } \\
\text { Permukaan } \\
\left(\mathrm{m}^{2} / \mathrm{g}\right)\end{array}$ & $\begin{array}{c}\text { Volume } \\
\text { Pori }\left(10^{-}\right. \\
\left.{ }^{3} \mathrm{cc} / \mathrm{g}\right)\end{array}$ & $\begin{array}{c}\text { Jari-Jari } \\
\text { Rerata } \\
\text { Pori }(\AA)\end{array}$ \\
\hline $\begin{array}{c}\text { Zeolit } \\
\text { Alam }\end{array}$ & 34,24 & 26,36 & 16,19 \\
\hline ZCBA & 38,89 & 53,49 & 27,51 \\
\hline
\end{tabular}


Fenomena transformasi terhadap modifikasi pori menjadi lebih dimengerti lagi dengan analisis distribusi pori sebagaimana terlihat pada gambar. 3. Hasil karakterisasi menggunakan TBA menunjukkan terjadi perubahan ukuran pori khususnya pada interval 30-40 Å dan 40-60 $\AA$, walaupun belum menghasilkan material dengan ukuran pori yang lebih seragam. Menurut Kresge,et.al (1995) untuk membuat material berpori dengan ukuran mayoritas diatas $20 \AA$ diperlukan sumber silikat yang tinggi atau rasio $\mathrm{Si} / \mathrm{Al}$ diatas 30 , sementara hasil analisis AAS terhadap zeolit hasil modifikasi rasio $\mathrm{Si} / \mathrm{Al}$ hanya 6,89. Dengan demikian faktor pembentukan pori tidak hanya ditentukan oleh adanya molekul pengarah saja tetapi sumber dan jumlah silikat yang direaksikan pada sintesis tersebut merupakan variabel yang dipertimbangkan.

\section{Identifikasi Struktur}

Dari spektra inframerah tersebut, dapat dilihat adanya perbedaan serapan antara sampel (b) dan (c) dimana pada (b) muncul serapan kuat pada daerah $1488 \mathrm{~cm}^{-1}$ dan $948 \mathrm{~cm}^{-1}$ yang mencerminkan masih adanya rantai $\mathrm{CH}_{2}$ - linier maupun cabang yang berasal dari molekul senyawa pengarah atau surfaktan pada proses sintesis. Namun setelah di kalsinasi sampel (c) terlihat serapan pada daerah tersebut menjadi hilang atau bebas dari molekul senyawa pengarah. Berkaitan dengan pembentukan pori, maka serapan khas untuk pore opening akan muncul pada daerah $420 \mathrm{~cm}^{-1}-300 \mathrm{~cm}^{-1}$ (Flanigen,1971).

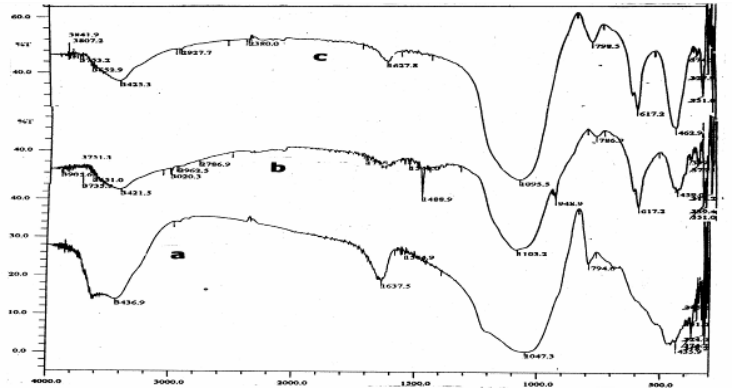

Gambar 3. Spektra inframerah (a) Zeolit alam (b) Zeolit antara (c) Zeolit Modifikasi

Untuk ketiga sampel tersebut atas serapan muncul pada bilangan gelombang $351 \mathrm{~cm}^{-1}$, dengan demikian semakin memperkuat analisis bahwa zeolit hasil modifikasi telah menjadi suatu material berpori sebagaimana jenis zeolitzeolit yang lain. Identifikasi struktur zeolit dengan infra merah adalah memilih rentang bilangan gelombang $1300-300 \mathrm{~cm}^{-1}$ (Flanigen,1971). Pada rentang ini kristal alumina silika mempunyai spektra yang khas. Zeolitzeolit hasil modifikasi dengan penambahan molekul pengarah struktur memberikan serapan yang dapat di identifikasi. Serapan pada sekitar bilangan gelombang $1078-1124 \mathrm{~cm}^{-1}$ sebagai vibrasi ulur asimetri dari eksternal dan internal tetrahedra, sedang serapan pada sekitar 777-795 $\mathrm{cm}^{-1}$ sebagai ulur simetri dari eksternal tetrahedra. Serapan pada $461-470 \mathrm{~cm}^{-1}$ yang merupakan vibrasi T-O tekuk dari tetrahedra internal. Penurunan bilangan gelombang tersebut seiring dengan meningkatnya rasio CTMA/Si, karena daerah tersebut merupakan vibrasi ulur asimetri dari eksternal dan internal tetrahedra sehingga diduga telah terjadi perubahan bentuk pori pada tahap sintesis. Hasil penelitian lainnya oleh Zhao, et al (1996) memperlihatkan bahwa konsentrasi surfaktan akan menentukan bentuk phase surfaktan yang akhirnya berpengaruh terhadap bentuk cetakan 
pori zeolit yang dibuat. Adanya serapan khas dari zeolit modifikasi pada serapan $617 \mathrm{~cm}^{-1}$ yang tidak muncul pada zeolit alam mencerminkan telah terjadi perubahan interaksi pada sistem tetrahedra. Serapan tersebut merupakan ulur simetri dari eksternal dan internal tetrahedra pada zeolit. Hasil kajian awal terhadap data-data spektra infra merah serta adanya kesamaan pada beberapa bilangan gelombang yang muncul dari beberapa jenis zeolit sintesis, maka yang paling mendekati adalah jenis zeolit Chabazite.

Hasil identifikasi struktur zeolit alam dan zeolit hasil modifikasi dapat dianalisis dengan memperhatikan pola difraksi dari difraktogram sinar-x zeolit tersebut seperti pada gambar 4.
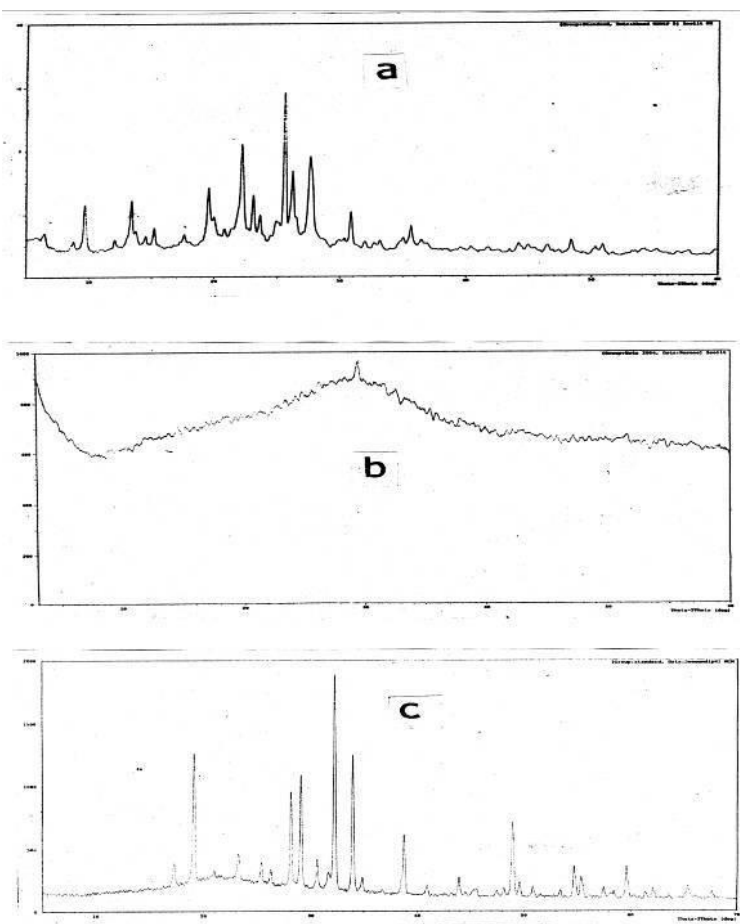

Gambar 4. Difraktogram (a) Zeolit alam (b) Zeolit terdistruksi (c) Zeolit modifikasi

Adapun krisitalinitas zeolit dapat diikuti dengan memperhatikan pergeseran sudut $2 \theta$, perubahan jarak antar bidang (d) dan kenaikan intensitas (I). Pemantauan terhadap 20, d dan I merujuk pada pada daerah sidik jari kristal zeolit alam. Pada penelitian ini penyisipan daerah sidik jari dilakukan dengan mengambil secara berturut turut sudut $2 \theta=25,58^{\circ} ; 22,17^{\circ}$ dan $27,66^{\circ}$. Analisis terhadap data pada tabel diatas semakin memperkuat bahwa telah terjadi perubahan stuktur kristal antara zeolit alam dan zeolit modifikasi dengan molekul pengarah TBA.

\section{Uji Aktivitas Amobilisasi Sel}

Prinsip penelitian ini adalah menggunakan zeolit sebagai padatan atau matriks dalam rangka mencari alternatif teknik preservasi sel mikroorganisme sebelum digunakan dalam fermentasi.

Hasil amobilisasi dengan zeolit alam maupun zeolit termodifikasi yang terimobilisasi dengan sel khamir dan disimpan selama 2 minggu menunjukkan bahwa sel khamir masih dapat tumbuh dan menghasilkan konsentrasi berat kering sel sebagai berikut Tabel 2. Dari percobaan tersebut memperlihatkan bahwa waktu penggojokan mempengaruhi terhadap hasil pertumbuhan sel khamir dengan adanya perbedaan konsentrasi berat kering sel antara tanpa dan digojok selama 1 jam. Hasil ini membuktikan bahwa zeolit alam yang termodifikasi dapat digunakan sebagai padatan dalam mendukung sel khamir, sehingga dapat dimanfaatkan sebagai alternatif cara preservasi sel mikroorganisme sebelum digunakan untuk fermentasi.

Tabel 3. Hasil pertumbuhan sel khamir $P$. rhodozyma (berat kering sel, $\mathrm{g} / \mathrm{L}$ ) selama inkubasi 6 hari setelah sel di amobilisasi dengan zeolit alam dan zeolit yang telah termodifikasi selama 2 minggu.

\begin{tabular}{|l|l}
\hline Sampel & Berat kering sel $(\mathrm{g} / \mathrm{L})$ \\
\hline
\end{tabular}




\begin{tabular}{|l|c|c|}
\hline & $\begin{array}{c}\text { Waktu } \\
\text { penggojokan } \\
0 \text { jam }\end{array}$ & $\begin{array}{c}\text { Waktu } \\
\text { penggojokan } \\
1 \text { jam }\end{array}$ \\
\hline Zeolit alam & 2,13 & 2,80 \\
\hline $\begin{array}{l}\text { Zeolit } \\
\text { termodifikasi }\end{array}$ & 1,60 & 2,40 \\
\hline
\end{tabular}

\section{KESIMPULAN}

Metode penambahan molekul pengarah struktur menggunakan TMA, TBA dan CTMA dapat menghasilkan zeolit baru dengan kekristalan tinggi dan ukuran pori yang bertambah hingga $70 \%$ dari ukuran pori semula serta mampu berfungsi sebagai padatan pendukung imobilisasi.

\section{DAFTAR PUSTAKA}

Abe, T.,Tochibana, Y.,Uenatsu, T.and Inamoto,M.,1995, Preparation and charactrization of $\mathrm{Fe}_{2} \mathrm{O}_{3}$, Nanoparticle in Mesopore

Silicate,J.Chem.Soc.Chem.Com.,16171618.

Barrer, M.M., 1982, Hydrothemal chemistry of Zeolite, Academic Press, Tokyo.

Beck, J.S., Vartuli, J.C., Roth, W.J., Ieonowicz, M.E., Kresge, C.T., Scmiitt, K.D., Chu, C.T-W, Olson, D.H., Shepparod, E.W., Mc cullen, S.B., Higgins, J.B. and Schlenken, J.L., 1992, A New Family of Mesopore Molucular Siseves Prepared in the Liquid Criystal Template, J.Am.Chem.Soc, 144, 10834-10843

Beck, J.S., US Patent No.5 057 296, Oct, 15,1991

Flegel,T.W. ,et.al., 1982, Immobilzed Mocrobial Enzymes and Cells, Proceeding of Regional Workshop, Mahidol University, Bangkok, Thailand.

Flanigen, E.M.,Khatami, H and Szymanski,H, 1971, Infrared Structural Studies of Zeolite Framework, Union Carbide Coorp, Linde Division laboratory, New York

Ishizaki, K. Komareni, S., and and Nanko, M., 1998, Porous Material Process
Tecnologyand applications Kluwer Academic Publissher, Netherlands

Hong-Ping Lin, Chung, Y.M.,Liu,S.B., tang, C.Y.J., Micro and Mesoporous Materials. 2001, 44, pp 129-137

Jacobsen, C.J.H., Madsen, C, Houzvieka, J., Mesopore Zeolite Singe Cristals, J.Am. Chem. Soc, 122, 7116-7117

Kresge,

C.T.,Leonowicz,M.E.,Roth,W.J.,Vartuli,J

.C. and Beck,J.S.,1992,Nature, 359,710.

Li, Zhohui, Browman, R.S., 1998, Sorption of Percloroethylena by surfactant-modified zeolite controlld by surfactant loading; Envirommental Science \& Tecnology, 32, 2278

Li, Zhohui, Burt, T., Browman, R.S.,2000, Sorption of Ionizable organic solutes by Surfactant-Modified Zeolite, Environmental Science \& Tecnology, 34, 2756

Suseno, A., Arnelli, 2003, Modifikasi pori zeolit alam menggunakan lauril benzil dimetil ammonium klorida sebagai molekul pengarah,Laporan Penelitian,FMIPA UNDIP, Semarang

Vansant, E.F.,1997,Molecular Enginering of Oxide and Zeolites,J.Mol.Catal, A Chemical, 115,179

Vansant, E.F., 2000, Chemical Modification of Oxide Surface, in Firsty Indonesian, Seminar on Zeolite, entitlr Zeolite for Indonesia Society Welfare, on May 2000, The Indonesian Zeolite Assosciation, Yogyakarta

Vansant, E.F., 1990,Pore Size Engineering in Zeolite,J W and Sons,Chicester, New York.

Zones, S.I., Nakagawa, Y., and Rosenthal, J.W., 1994, Factors Afeefcting the Selectivities of Organo-cation Guest Moleculs in the Synthesis of Hight silioca Zeolites, in the Synthesis of Microporous Materials, Vol II Eds M.I., Occelli and H.E. Robson , Van Nostrand Reinhold, New York.

Zhao, X.S., Lu, G.Q., Millar, G.J., 1996, Advances in Mesoporous Molecular Sieve MCM-41, Ind.Eng.Chem.Res, $1996,35,2075-2090$ 